\title{
Integrated nutrient management on soil fertility, growth and yield of tomato
}

\author{
M. R. Islam, M.A.H. Chowdhury*, B. K. Saha and M. M. Hasan \\ Department of Agricultural Chemistry, Bangladesh Agricultural University, Mymensingh-2202, Bangladesh \\ *Email: akhterbau11@yahoo.com
}

\begin{abstract}
To evaluate the effects of integrated nutrient management on growth and yield of BARI tomato-14 and soil fertility, a pot experiment was conducted in the net house of the department of Agricultural Chemistry of Bangladesh Agricultural University, Mymensingh during the period from October 2011 to April 2012. The experiment was laid out in a completely randomized design with 11 treatments and 3 replications. Treatments were control, $\mathrm{RDCF}_{100,75 \%}$ RDCF, 50\% RDCF, 75\% RDCF + $\mathrm{PM}_{2 \mathrm{t} / \mathrm{ha}}, 75 \% \mathrm{RDCF}+\mathrm{RS}_{3 \mathrm{t} / \mathrm{ha}}, 75 \% \mathrm{RDCF}+\mathrm{PH}_{\mathrm{RD}}, 50 \% \mathrm{RDCF}+\mathrm{PM}_{3 \mathrm{t} / \mathrm{ha}}, 50 \%$ $\mathrm{RDCF}+\mathrm{RS}_{5 \mathrm{t} / \mathrm{ha}}, 50 \% \mathrm{RDCF}+\mathrm{PH}_{\mathrm{RD}}, \mathrm{PM}_{3 \mathrm{t} / \mathrm{ha}}+\mathrm{RS}_{5 \mathrm{t} / \mathrm{ha}}+\mathrm{PH}_{\mathrm{RD}}$. Among the treatments applied in combination of $\mathrm{PM}_{2}$ $\mathrm{t} / \mathrm{ha}+75 \%$ of RDCF excelled in growth trends of morphological characters like plant height, number of branches plant ${ }^{1}$, number of leaves plant ${ }^{-1}$; available soil $\mathrm{P}$ and $\mathrm{S}$. But sole application of $\mathrm{RDCF}_{100}$ recorded higher values for almost all morphological characters namely number of branches plant ${ }^{-1}$, number of leaves plant ${ }^{-1}$, fruit diameter, fruit weight plant $^{-1}$ and yield of tomato following the same trend as seen in combined application of CF and PM. Among the plant hormone applied in combination, $\mathrm{RDCF}_{75 \%}+\mathrm{PH}_{\mathrm{RD}}$ showed the highest plant height. The more number of leaves plant $^{-1}$, number of branches plant ${ }^{-1}$, yield and yield parameters as compared to other treatments were also significantly influenced by application of $\mathrm{PH}$. Combined application of $50 \%$ of $\mathrm{RDCF}+\mathrm{RS}_{5} \mathrm{t} / \mathrm{ha}$ increased exchangeable soil K. $\mathrm{PM}_{3 \mathrm{t} / \mathrm{ha}}+\mathrm{RS}_{5 \mathrm{t} / \mathrm{ha}}+\mathrm{PH}_{\mathrm{RD}}$ conserved more organic carbon and total soil $\mathrm{N}$. Results showed that the integrated use of PM, RS along with CF increased the availability of nutrients throughout the growth period by maintaining the long term productivity for sustainable production of tomato.
\end{abstract}

Keywords: Tomato, Integrated nutrient management, Growth, Yield and Soil fertility

\section{Introduction}

Integrated nutrient management is an advanced concept of modern agriculture. Application of chemical fertilizers provides a good yield but soil properties are badly affected. Keeping in mind the bad impact of chemical fertilizers use only, the concept of integrated nutrient management is taken under consideration to obtain a higher yield and good quality. So an experiment has been conducted by combining different organic and inorganic fertilizers in a frame which is rare in the field of tomato research. The research has been performed using tomato as a test crop because it is one of the most popular, nutritious and widely grown vegetables not only in Bangladesh but also other parts of the world.

Organic fertilizers contain relatively low concentrations of nutrients as compared to chemical one, but they perform important functions which the chemical fertilizers do not do. The use of organic fertilizers and their proper management may reduce the need for chemical fertilizers thus allowing the small farmers to save in part the cost of production. In addition, the release pattern of inorganic fertilizers compared to organic one is higher. As a result, released nutrients are used and lost rapidly by different means. On the other hand, organic fertilizers were decomposed slowly and nutrients are available for longer period of time which helps to maintain soil nutrient status.

In Bangladesh, the yield of tomato is not yet satisfactory as compared to other tomato growing countries of the world. Organic manure (poultry manure, rice straw), plant hormone and chemical fertilizers play an important role in increasing growth and yield of crops. That is why, it is necessary to adopt integrated nutrient management system through combined application of organic and inorganic fertilizers to boost up the crop growth and yield without affecting soil fertility. 


\section{Materials and Methods}

A pot experiment was carried out in the net house of the Department of Agricultural Chemistry, Bangladesh Agricultural University (BAU), Mymensingh during the period from October 2011 to April 2012. There were altogether 11 treatment combinations. The experiment was laid out in Completely Randomized Design with three replications. Treatments were control (CT), recommended dose of chemical fertilizer $\left(\mathrm{RDCF}_{100}\right), 75 \% \mathrm{RDCF}, 50 \% \mathrm{RDCF}, 75 \% \mathrm{RDCF}+$ poultry manure @ $2 \mathrm{t} \mathrm{ha} \mathrm{H}^{-1}\left(\mathrm{PM}_{2 \mathrm{t} / \mathrm{ha}}\right)$, $75 \%$ RDCF + rice straw @ $3 \mathrm{t} \mathrm{ha}^{-1}\left(\mathrm{RS}_{3 \mathrm{t} / \mathrm{ha}}\right), 75 \% \mathrm{RDCF}+$ plant hormone @ recommended dose $\left(\mathrm{PH}_{\mathrm{RD}}\right)$, $50 \% \mathrm{RDCF}+$ poultry manure @ $3 \mathrm{t} \mathrm{ha}^{-1}\left(\mathrm{PM}_{3} \mathrm{t} / \mathrm{ha}\right), 50 \% \mathrm{RDCF}+$ rice straw @ $5 \mathrm{t} \mathrm{ha}^{-1}\left(\mathrm{RS}_{5} \mathrm{t} / \mathrm{ha}\right), 50 \%$ $\mathrm{RDCF}+\mathrm{PH}_{\mathrm{RD}}, \mathrm{PM}_{3 \mathrm{t} / \mathrm{ha}}+\mathrm{RS}_{5 \mathrm{t} / \mathrm{ha}}+\mathrm{PH}_{\mathrm{RD}}$. The total number of pots were 33 each having the diameter of $35 \mathrm{~cm}$ and $30 \mathrm{~cm}$ depth. Initial soil sample was collected from the field laboratory of the department of Genetics and Plant Breeding of BAU, Mymensingh. The collected soils from $0-15 \mathrm{~cm}$ depth were pulverized and inert materials, visible insect pests and plant residues were removed. The soil was air dried and then rice straw and poultry manure were mixed with soil 7 days before transplanting @ 2, $3 \mathrm{t}$ $\mathrm{ha}^{-1}$ and $3,5 \mathrm{tha}^{-1}$, respectively as per treatment. The processed soil samples were placed in the pots at the rate of $10 \mathrm{~kg} \mathrm{pot}^{-1}$. Initial soil was analyzed to determine organic matter $(1.06 \%)$, total soil $\mathrm{N}(0.10 \%)$, available $\mathrm{P}\left(19.25 \mathrm{\mu g} \mathrm{g}^{-1}\right.$ soil), exchangeable $\mathrm{K} \quad\left(0.16 \mathrm{cmol}^{100 \mathrm{~g}^{-1} \text { soil), available } \mathrm{S}(10.9 \mu \mathrm{g} \mathrm{g}}{ }^{-1}\right.$ soil) and pH (6.18) by the method described by Jackson (1973), Page et al. (1982) before mixing RS and PM. Fertilizers were added as per treatment and mixed uniformly with the soil. Urea was applied in two installments, one half during pot preparation and the rest 30 days after transplanting. Recommended doses of TSP and MOP were mixed thoroughly with soil. Plant hormone $(\mathrm{PH})$ was sprayed during first flowering and 30 days after 1st application. Tomato seeds were collected from Horticulture division, Bangladesh Agricultural Research Institute, Gazipur. Seeds were sown in pot having highly friable loose soil and one month old three seedlings were transplanted to each prepared pot. Two seedlings were removed 15 and 23 days after transplanting from the pot keeping the healthy one undisturbed. All necessary intercultural operations (watering, staking, pest control, weeding etc.) were performed as and when necessary throughout the growth period of the crop. Irrigation was done regularly to the pots. Agronomic characteristics were collected and recorded. Fruits were harvested thrice at full maturity stage of tomato. Post harvest soil was analyzed to determine organic matter, total soil $\mathrm{N}$, available $\mathrm{P}$, exchangeable $\mathrm{K}$, available $\mathrm{S}$ and $\mathrm{pH}$. Analysis of variance was done with the help of computer package program MSTAT-C according to Gomez and Gomez (1984) and the mean differences among the different treatments were adjudged by DMRT test at $5 \%$ level of probability.

\section{Results and Discussion}

\section{Growth and yield contributing characters of BARI tomato-14}

Plant height: Integrated use of organic and inorganic fertilizers had a significant and positive influence on the height of tomato plant. The plant height increased slowly up to 30 days after transplanting (DAT) and then increased rapidly up to 75 DAT and then remained almost same. All the treatments followed the almost similar trends due to the application of different fertilizers. The plant height ranged from 58.00 to $87.67 \mathrm{~cm}$ at 90 DAT. The highest plant height in $75 \% \mathrm{RDCF}+\mathrm{PH}_{\mathrm{RD}}$ treatment at $90 \mathrm{DAT}$ might be due to the application of plant hormone and $75 \%$ chemical fertilizers and lowest plant height might be due to neither the application of fertilizers nor plant hormone. The application of plant hormone resulted the increased plant height as plant growth regulators enhanced cell division with considerable elongation of stem and the ultimate result was the longest plant of tomato. Sittu and Adeleke (1999) and Wu et al. (1983) reported the same trend of the results on tomato. Begum (2006) reported that application of plant hormone like GABA @ $2.0 \mathrm{mg} \mathrm{L}^{-1}$ increased plant height in mustard. But Chhonkar and Ghufran (1968) reported that plant height decreased with the increased concentration of hormone which was not similar to that of the present study. 


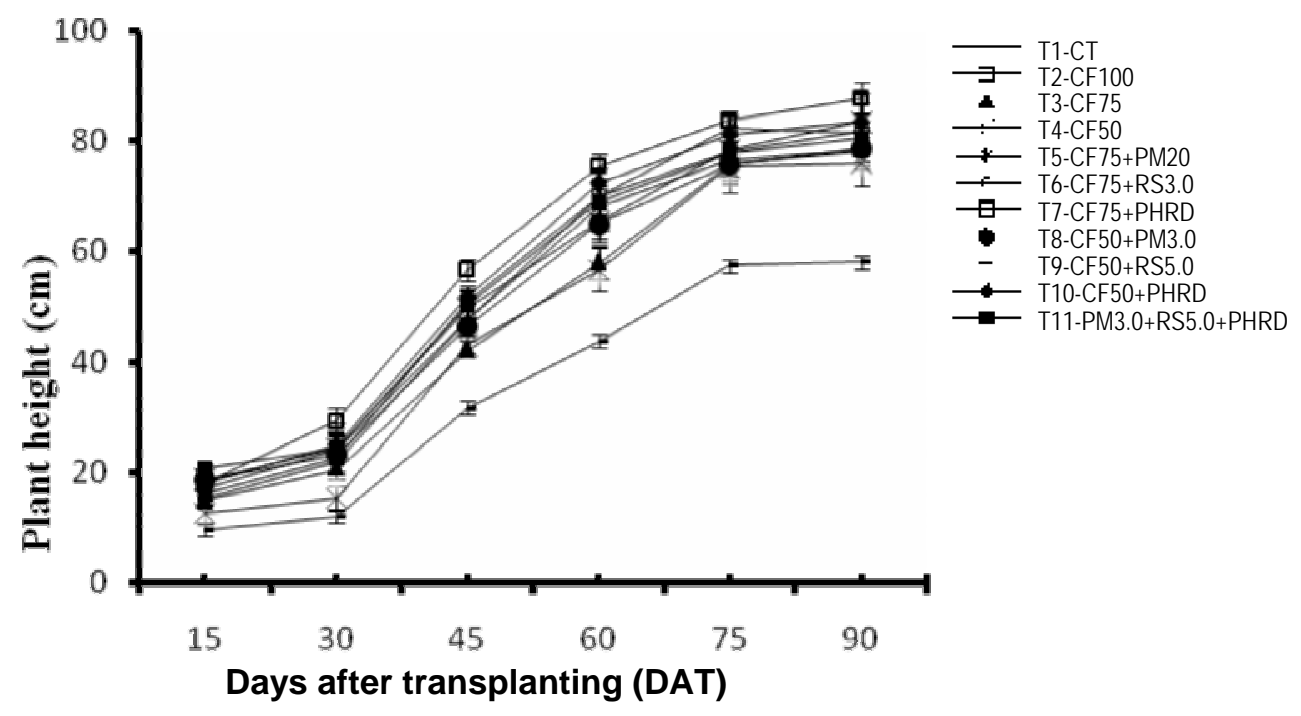

Fig. 1. Effect of integrated nutrient management on plant height in BARI tomato-14 $(\perp$ indicates standard error bar)

Number of branches plant ${ }^{-1}$ : Application of organic and inorganic fertilizers had a significant influence on number of branches plant ${ }^{-1}$. The number of branches plant ${ }^{-1}$ increased up to 75 DAT and then remained almost constant. The number of branches plant ${ }^{-1}$ ranged from 2 to 4 . However, it is clear from Fig. 2 that number of branches plant ${ }^{-1}$ was 1 and 2 at 15 DAT and 30 DAT, respectively. The number of the branches was higher in $\mathrm{RDCF}_{100}$ and $75 \% \mathrm{RDCF}+\mathrm{PM}_{2 \mathrm{t} / \mathrm{ha}}$ treatments for releasing sufficient nutrients throughout the growth period. The plants of other treatments contained branches in a similar pattern due to moderate releasing nutrient throughout the growth period. On the other hand, the lowest number of branches was observed in control treatment without fertilizers. Patil et al. (2004) also stated that the application of recommended dose of chemical fertilizer $+50 \%$ of FYM significantly increased the number of branches plant ${ }^{-1}$ of tomato plants.

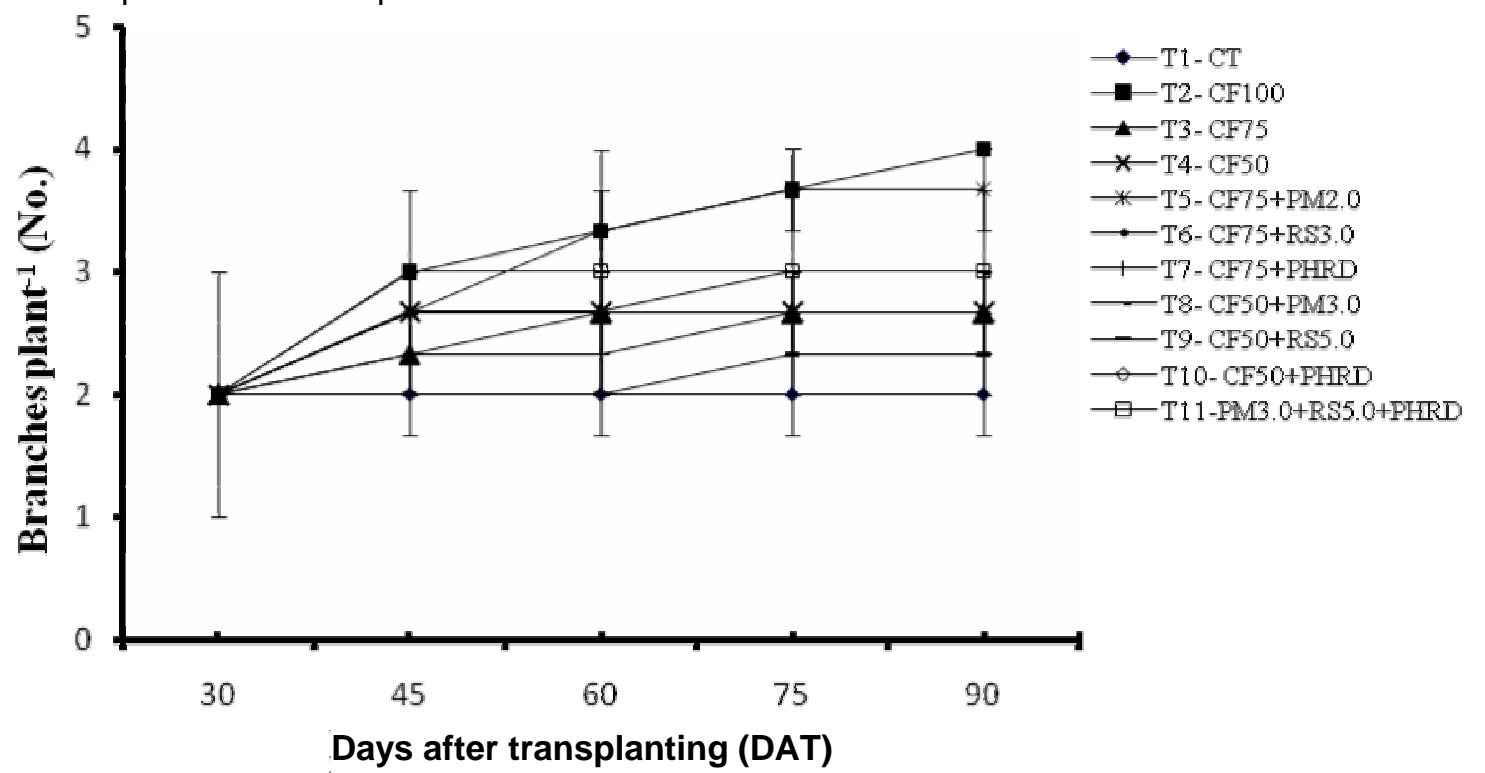

Fig. 2. Effect of integrated nutrient management on number of branches plant ${ }^{-1}$ in BARI tomato-14 $(\perp$ indicates standard error bar) 
Number of leaves plant ${ }^{-1}$ : It observed that the number of leaves was significantly (except 15 DAT) influenced by the application of different doses of organic and chemical fertilizers. The effects of different treatments on number of leaves plant ${ }^{-1}$ of BARI tomato- 14 are presented in Fig. 3 . The number of leaves plant $^{-1}$ ranged from 9.00 to 30.67 . The numbers of leaves plant ${ }^{-1}$ in RDCF $_{100}$ treatment were abruptly increased after 60 DAT up to 75 DAT might be due to the application of $2^{\text {nd }}$ installment chemical fertilizers. For other treatments, the numbers of leaves plant ${ }^{-1}$ were gradually increased up to 75 DAT and then gradually decreased. However, it is clear from Fig. 3 that number of leaves plant ${ }^{-1}$ was higher in the treatment where full doses of chemical fertilizers were applied and almost same number of the leaves were observed where chemical and organic fertilizers were applied in integrated pattern might be due to sufficient nutrient throughout the growth period. On the other hand, lowest number of leaves was obtained in the control treatment where no fertilizers were applied. Patil et al. (2004) also stated that the application of recommended dose of chemical fertilizer $+50 \%$ of FYM significantly increased the number of leaves of tomato plants.

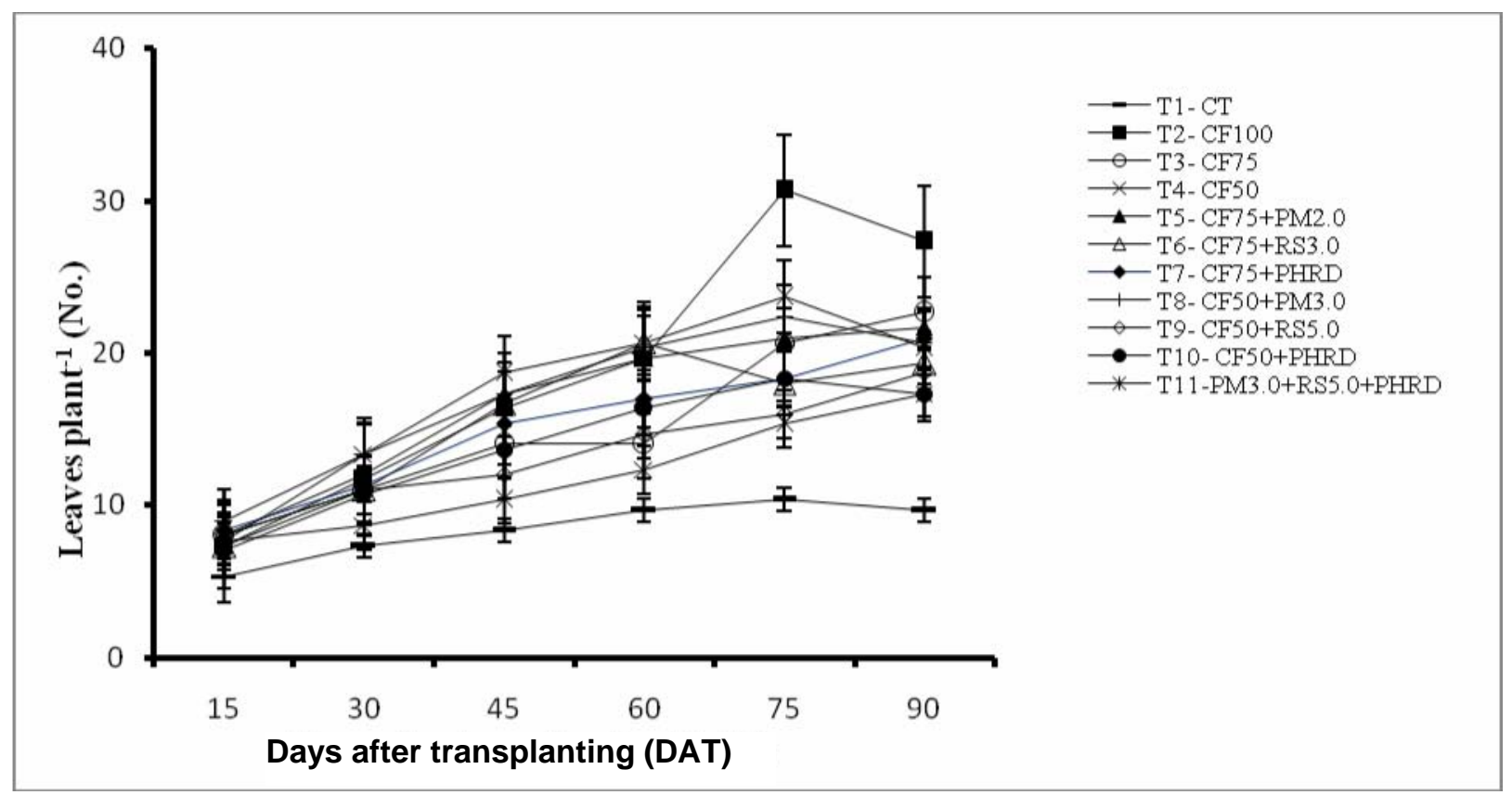

Fig. 3. Effect of integrated nutrient management on number of leaves plant $^{-1}$ in BARI tomato-14 $(\perp$ indicates standard error bar)

Number of flower cluster plant ${ }^{-1}$ : Combined application of organic and inorganic fertilizers had a significant influence (except 15 DAT) on number of cluster of flower plant ${ }^{-1}$. From the observations, it is clear that flowering started within one month of transplanting. The highest number of cluster of flower plant $^{-1}$ was observed 6.67 in $75 \% \mathrm{RDCF}+\mathrm{PM}_{2} \mathrm{t} / \mathrm{ha}$ treatment and the lowest was recorded 2.33 in control treatment at 75 DAT. The number of cluster of flower plant ${ }^{-1}$ was gradually increased up to 75 DAT and then decreased (except control treatment). It might be due to environmental factors as effective flower production was reduced with the increasing of temperature during February and March. The reasons of obtaining comparatively higher flower cluster might be due to the contribution of integrated use of chemical fertilizers and poultry manure (Farhad et al., 2009). 


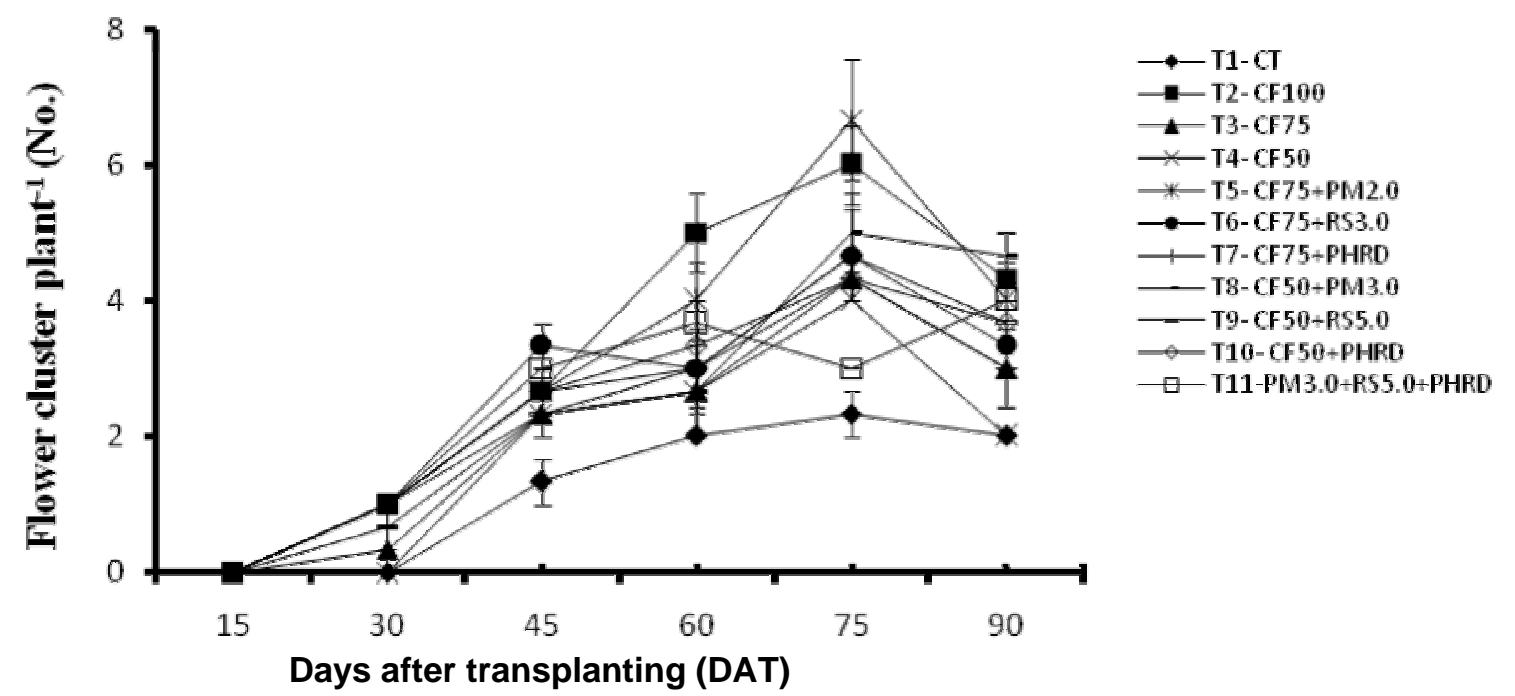

Fig. 4. Effect of integrated nutrient management on number of flower cluster plant ${ }^{-1}$ in BARI tomato-14 $(\perp$ indicates standard error bar)

Number of fruits plant ${ }^{-1}$ : The number of fruits plant $^{-1}$ was significantly influenced (except 15 and 30 DAT) by the application of different levels of organic manure with different doses of chemical fertilizers. The number of fruits increased abruptly up to 75 DAT and then gradually decreased. The highest number of fruits plant ${ }^{-1}$ (15.67) was produced in $\mathrm{RDCF}_{100}$ treatment whereas lowest (5.00) was in control treatment at 75 DAT as shown in Fig. 5 . The number of the fruits was higher in treatment where plants obtained nutrients when necessary in sufficient amount throughout the growth period. The number of fruits plant $^{-1}$ were gradually increased up to 75 DAT and then decreased. It might be due to lower production of effective flowers (due to increasing temperature) resulted the less amount of fruits plant ${ }^{-1}$ (Farhad et al., 2009). The number of the fruits was lower in control treatment.

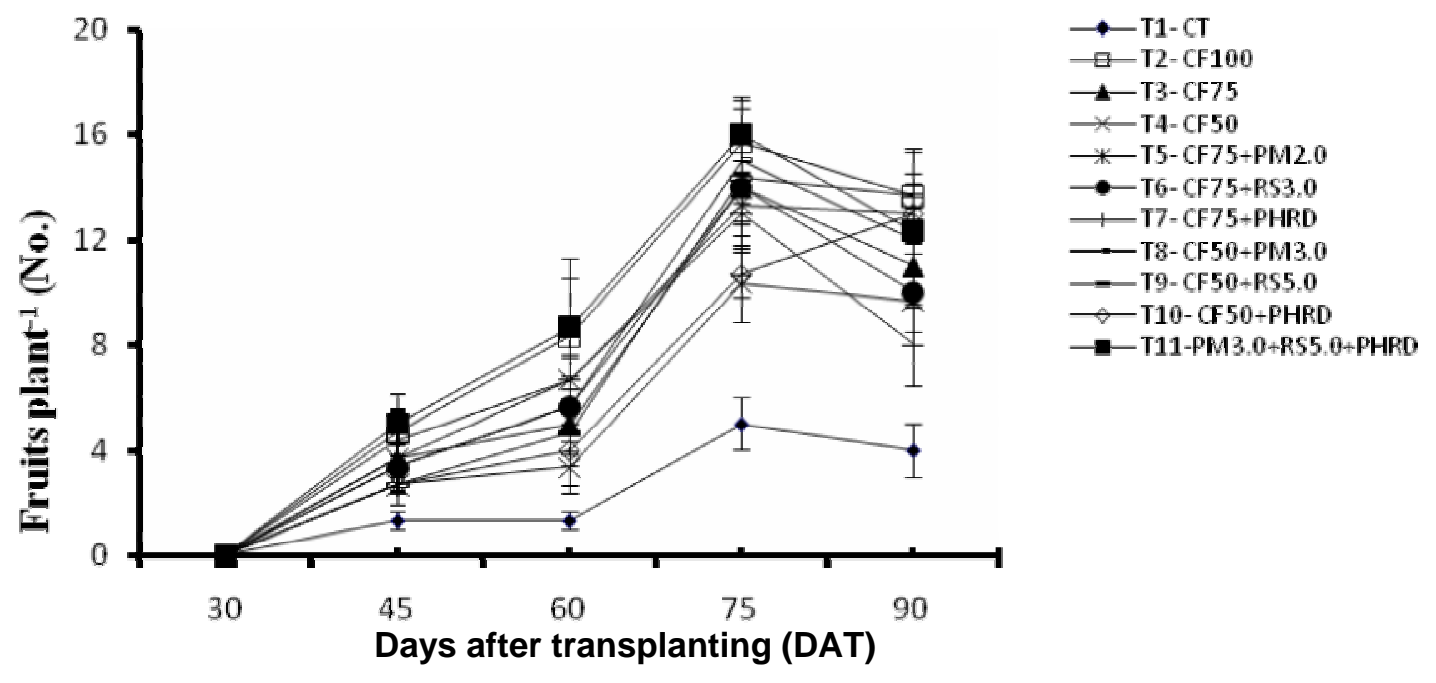

Fig. 5. Effect of integrated nutrient management on number of fruits plant $^{-1}$ in BARI tomato-14 $\left(\perp^{\perp}\right.$ indicates standard error bar) 
Fruit diameter: The fruit diameter varied significantly due to the application of organic along with chemical fertilizers (Table 1). The highest fruit diameter $(44.77 \mathrm{~mm})$ was found at $\mathrm{RDCF}_{100}$ treatment and the lowest diameter $(24.28 \mathrm{~mm})$ in control treatment. The diameter of the fruits was the highest in treatment where plants were supplied nutrients from chemical fertilizers that were readily available to the plants in sufficient amount throughout the growth period. The diameter of fruits of the other treatments were almost similar might be due to the combined application of organic and inorganic fertilizers. On the other hand, the diameter of the fruits was the lowest in control treatment.

Fruit yield: The fruit yield of tomato was significantly different with the application of organic with or without different levels of chemical fertilizers. The highest fruit yield $\left(1023 \mathrm{~g} \mathrm{pot}^{-1}\right)$ and the second highest yield $\left(1048.33 \mathrm{~g} \mathrm{pot}^{-1}\right)$ was recorded in $\mathrm{RDCF}_{100}$ and $75 \% \mathrm{RDCF}+\mathrm{PM}_{2} \mathrm{t} / \mathrm{ha}$ treatments respectively and the lowest yield (124.33 $\mathrm{g} \mathrm{pot}^{-1}$ ) was observed in control treatment (Table 1). The results indicated that the application of full recommended dose of chemical fertilizers $\left(\mathrm{RDCF}_{100}\right)$ had the best effect on yield of tomato. The application of $75 \%$ of recommended dose of chemical fertilizer with poultry manure $2 \mathrm{t} \mathrm{ha}^{-1}$ $\left(75 \% \mathrm{RDCF}+\mathrm{PM}_{2} \mathrm{t} / \mathrm{ha}\right)$ was as good as $\mathrm{RDCF}_{100}$ regarding fruit yield of tomato. The application of no fertilizers (control) provided the lowest yield of tomato might be due to shortage of nutrients throughout the growth period. Yongchung et al. (2004) also reported that the yield of tomato fruits from the organicinorganic combined fertilized plants was significantly higher among all the treatments.

Table 1. Effect of integrated nutrient management on fruit diameter and fruit yield of BARI tomato-14

\begin{tabular}{|c|c|c|}
\hline Treatments & Fruit diameter $(\mathrm{mm})$ & Fruit yield $\left(\mathrm{g} \mathrm{pot}^{-1}\right)$ \\
\hline Control & $24.28 d$ & $124.33 \mathrm{e}$ \\
\hline $\mathrm{CF}_{100}$ & $44.77 a$ & $1053.00 a$ \\
\hline $\mathrm{CF}_{75}$ & $35.46 a b c$ & $723.67 \mathrm{bc}$ \\
\hline $\mathrm{CF}_{50}$ & $30.68 \mathrm{bcd}$ & $451.00 d$ \\
\hline $\mathrm{CF}_{75}+\mathrm{PM}_{2.0}$ & $42.91 a$ & 1048.33a \\
\hline $\mathrm{CF}_{75}+\mathrm{RS}_{3.0}$ & 40.48ab & $843.00 \mathrm{~b}$ \\
\hline $\mathrm{CF}_{75}+\mathrm{PH}_{\mathrm{RD}}$ & $36.59 a b c$ & $758.67 \mathrm{bc}$ \\
\hline $\mathrm{CF}_{50}+\mathrm{PM}_{3.0}$ & $31.15 \mathrm{bcd}$ & $679.00 c$ \\
\hline $\mathrm{CF}_{50}+\mathrm{RS}_{5.0}$ & $27.74 \mathrm{~cd}$ & $667.67 c$ \\
\hline $\mathrm{CF}_{50}+\mathrm{PH}_{\mathrm{RD}}$ & $28.48 \mathrm{~cd}$ & $644.00 \mathrm{c}$ \\
\hline $\mathrm{PM}_{3.0}+\mathrm{RS}_{5.0}+\mathrm{PH}_{\mathrm{RD}}$ & $34.54 a-d$ & $702.67 \mathrm{bc}$ \\
\hline CV (\%) & 3.96 & 6.45 \\
\hline
\end{tabular}

Same letter in a column are not significantly different at $5 \%$ level of probability by DMRT.

$\mathrm{CV}=$ Coefficient of variation, $\mathrm{CT}=$ Control, $\mathrm{CF}=$ Chemical Fertilizer, $\mathrm{PM}=$ Poultry Manure, $\mathrm{RS}=$ Rice Straw, $\mathrm{PH}=$ Plant Hormone, RD = Recommended Dose.

\section{Nutrient status of post-harvest soil}

Soil pH: The pH of post-harvest soil was affected by different treatments and ranged from 5.33 to 6.88 (Table 2). Maximum value of soil $\mathrm{pH}$ (6.88) was found from combined application of poultry manure, rice straw and plant hormone in treatment $\mathrm{PM}_{3 \mathrm{t} / \mathrm{ha}}+\mathrm{RS}_{5 \mathrm{t} / \mathrm{ha}}+\mathrm{PH}_{\mathrm{RD}}$ and minimum value of soil pH (5.33) was obtained in $\mathrm{RDCF}_{100}$ treatment. The application of organic manure decreased soil $\mathrm{pH}$ as it released acids upon decomposition. The $\mathrm{pH}$ of post-harvest soil was lowest in the treatment $\mathrm{RDCF}_{100}$ might be due to the application of acid forming fertilizer (eg. Urea). On the other hand, treatments where rice straw was applied resulted higher in $\mathrm{pH}$ due to higher $\mathrm{Ca}$ content. Man and $\mathrm{Ha}$ (2006) reported that the application of rice straw increased the soil $\mathrm{pH}$.

Organic carbon: Organic $C$ of the post-harvest soil was significantly influenced by different treatments (Table 2). Organic $C$ varies from 0.51 to 1.22 . Maximum organic $C(1.22 \%)$ was found from $P_{3} M_{3 / h a}+R S_{5}$ $\mathrm{t} / \mathrm{ha}+\mathrm{PH}_{\mathrm{RD}}$ treatment and minimum (0.51\%) in control treatment (Table 2). Organic $\mathrm{C}$ increased due to the application of poultry manure and rice straw. The organic carbon of post-harvest soil was lower in the treatments where no organic manure was applied. On the other hand, treatments where organic manure was applied resulted in higher organic carbon. The combined application of organic manure and chemical fertilizers increased organic matter content in soil (Zhang et al., 2009). 
Total nitrogen: Total $\mathrm{N}$ content of post-harvest soil varied from 0.01 to $0.41 \%$ due to different treatments (Table 2). The highest $\mathrm{N}$ content $(0.41 \%)$ was found from the combined application of poultry manure, rice straw in $\mathrm{PM}_{3 \mathrm{t} / \mathrm{ha}}+\mathrm{RS}_{5 \mathrm{t} / \mathrm{ha}}+\mathrm{PH}_{\mathrm{RD}}$ treatment and lowest from control treatment. The total nitrogen of post-harvest soil was higher in the treatments where either organic or both organic and chemical fertilizers were applied. On the other hand, in control treatment total nitrogen was lower due to neither application of chemical fertilizers nor organic manures. Several researchers reported that combined application of poultry manure, rice straw, vermicompost and chemical fertilizers increased total $\mathrm{N}$ content in the post-harvest soils (Reddy et al., 1998).

Available phosphorus: The content of available $P$ in post-harvest soil was significantly influenced by various treatments (Table 2). Available $P$ content varied from 7.40 to $20.79 \mu^{-1} g^{-1}$ soil. The highest value of available $\mathrm{P}\left(20.79 \mu \mathrm{g} \mathrm{g}^{-1}\right.$ soil) was obtained from full recommended dose of chemical fertilizer in $\mathrm{RDCF}_{100}$ treatment and the lowest from control treatment. Soils treated with either organic fertilizers, inorganic fertilizers or combined application of organic and inorganic fertilizers gave higher values of available $\mathrm{P}$ compared to control.

Exchangeable potassium: Exchangeable $\mathrm{K}$ of the post-harvest soil was significantly influenced by different treatments. The highest exchangeable $\mathrm{K}\left(0.27 \mathrm{cmol} 100 \mathrm{~g}^{-1}\right.$ soil) in post-harvest soil was obtained from $50 \% \mathrm{RDCF}+\mathrm{RS}_{5 \mathrm{t} / \mathrm{ha}}$ treatment and the lowest $\mathrm{K}\left(0.14 \mathrm{cmol} 100 \mathrm{~g}^{-1}\right.$ soil $)$ in the control treatment (Table 2). The exchangeable $\mathrm{K}$ of post-harvest soil was higher in the treatments where only organic or both organic and chemical fertilizers were applied. On the other hand, treatments where no fertilizer was applied resulted lower exchangeable potassium. Application of organic fertilizers significantly improved the exchangeable $\mathrm{K}$ in soil (Abdel and Hussain, 2001).

Available sulphur: Available $S$ content in the post-harvest soil significantly influenced by various treatments. The available $S$ in post-harvest soil ranged from 3.29 to $14.23 \mu g^{-1}$ soil. The highest and lowest available $S$ contents were obtained in $\mathrm{PM}_{3} \mathrm{t} / \mathrm{ha}+\mathrm{RS}_{5 \mathrm{t} / \mathrm{ha}}+\mathrm{PH}_{\mathrm{RD}}$ and control treatments (Table 2) respectively. The available $S$ of post-harvest soil was higher in the treatments where organic fertilizers were applied for slow released pattern of nutrients. On the other hand, in control treatment no organic and chemical fertilizers were applied resulted lower available S.

Table 2. Effect of integrated nutrient management on nutrient status of post- harvest soils

\begin{tabular}{|l|c|c|c|c|c|c|}
\hline Treatments & Soil pH & $\begin{array}{c}\text { Soil } \\
\text { organic } \\
\text { carbon }(\%)\end{array}$ & $\begin{array}{c}\text { Total } \\
\text { soil N } \\
(\%)\end{array}$ & $\begin{array}{c}\text { Available } \\
\text { soil } \mathrm{P}(\mu \mathrm{g} \\
\mathrm{g}^{-1} \text { soil) }\end{array}$ & $\begin{array}{c}\text { Exchangeable } \\
\text { Soil K (cmol } \\
100^{-1} \mathrm{~g} \text { soil) }\end{array}$ & $\begin{array}{c}\text { Available } \\
\text { soil S }\left(\mu \mathrm{g} \mathrm{g}^{-1}\right. \\
\text { soil) }\end{array}$ \\
\hline Control & $5.90 \mathrm{bc}$ & $0.51 \mathrm{~d}$ & $0.01 \mathrm{c}$ & $7.40 \mathrm{c}$ & $0.14 \mathrm{~b}$ & $3.29 \mathrm{c}$ \\
\hline $\mathrm{CF}_{100}$ & $5.33 \mathrm{e}$ & $0.77 \mathrm{c}$ & $0.37 \mathrm{ab}$ & $20.79 \mathrm{a}$ & $0.27 \mathrm{a}$ & $9.18 \mathrm{ab}$ \\
\hline $\mathrm{CF}_{75}$ & $5.47 \mathrm{cde}$ & $0.74 \mathrm{~cd}$ & $0.34 \mathrm{ab}$ & $16.62 \mathrm{ab}$ & $0.25 \mathrm{a}$ & $7.01 \mathrm{bc}$ \\
\hline $\mathrm{CF}_{50}$ & $5.73 \mathrm{~b}-\mathrm{e}$ & $0.74 \mathrm{~cd}$ & $0.30 \mathrm{ab}$ & $12.94 \mathrm{bc}$ & $0.22 \mathrm{a}$ & $5.49 \mathrm{bc}$ \\
\hline $\mathrm{CF}_{75}+\mathrm{PM}_{2.0}$ & $5.57 \mathrm{de}$ & $1.07 \mathrm{~b}$ & $0.36 \mathrm{ab}$ & $19.18 \mathrm{ab}$ & $0.26 \mathrm{a}$ & $9.29 \mathrm{ab}$ \\
\hline $\mathrm{CF}_{75}+\mathrm{RS}_{3.0}$ & $5.81 \mathrm{bcd}$ & $1.09 \mathrm{~b}$ & $0.34 \mathrm{ab}$ & $17.67 \mathrm{ab}$ & $0.25 \mathrm{a}$ & $8.37 \mathrm{bc}$ \\
\hline $\mathrm{CF}_{75}+\mathrm{PH}_{\mathrm{RD}}$ & $5.62 \mathrm{cde}$ & $0.77 \mathrm{c}$ & $0.31 \mathrm{ab}$ & $16.92 \mathrm{ab}$ & $0.24 \mathrm{a}$ & $7.34 \mathrm{bc}$ \\
\hline $\mathrm{CF}_{50}+\mathrm{PM}_{3.0}$ & $5.64 \mathrm{cde}$ & $1.12 \mathrm{ab}$ & $0.38 \mathrm{ab}$ & $15.79 \mathrm{ab}$ & $0.25 \mathrm{a}$ & $10.52 \mathrm{ab}$ \\
\hline $\mathrm{CF}_{50}+\mathrm{RS}_{5.0}$ & $6.02 \mathrm{~b}$ & $1.14 \mathrm{ab}$ & $0.35 \mathrm{ab}$ & $14.08 \mathrm{abc}$ & $0.27 \mathrm{a}$ & $7.07 \mathrm{bc}$ \\
\hline $\mathrm{CF}_{50}+\mathrm{PH}_{\mathrm{RD}}$ & $5.67 \mathrm{cde}$ & $0.78 \mathrm{c}$ & $0.28 \mathrm{ab}$ & $12.54 \mathrm{bc}$ & $0.22 \mathrm{a}$ & $6.75 \mathrm{bc}$ \\
\hline $\mathrm{PM}_{3.0}+\mathrm{RS}_{5.0}+\mathrm{PH}_{\mathrm{RD}}$ & $6.88 \mathrm{a}$ & $1.22 \mathrm{a}$ & $0.41 \mathrm{a}$ & $16.75 \mathrm{ab}$ & $0.24 \mathrm{a}$ & $14.23 \mathrm{a}$ \\
\hline $\mathrm{CV}(\%)$ & 1.26 & 4.04 & 6.42 & 5.31 & 3.33 & 7.81 \\
\hline
\end{tabular}

Same letter in a column are not significantly different at $5 \%$ level of probability by DMRT.

$\mathrm{CV}=$ Coefficient of variation, $\mathrm{CT}=$ Control, $\mathrm{CF}=$ Chemical Fertilizer, $\mathrm{PM}=$ Poultry Manure, $\mathrm{RS}=\mathrm{Rice} \mathrm{Straw}, \mathrm{PH}=$ Plant Hormone, RD = Recommended Dose. 


\section{References}

Abdel, N.G. and Hossein, A.H.A. 2001. Effect of different manure sources on some soil properties and sunflower plant growth. Axeandria J. Res., 46(1): 227-251.

Begum, M.M. 2006. Effect of GABA on growth and yield of mustard. MS Thesis. Department of Crop Botany, Bangladesh Agricultural University, Mymensingh.

Black, C.A. 1965. Methods of Soil Analysis. Part-II. Amer. Soc. Agron. Inc. Medison, Washington, USA. p. 999-1492.

Chhonkar, V.S. and Ghufran, M.H. 1968. Effect of starters and NAA on growth and yield of Lycopersicon esculentum. Indian J. Hort., 25: 72-75.

Farhad, W., Saleem, M.F., Cheema, M.A. and Hammad, H.M. 2009. Effect of poultry manure levels on the productivity of spring maize. J. Animal \& Plant Sci., 19(3): 122-125.

Gomez, A.K. and Gomez, A.A. 1984. Statistical Procedures for Agricultural Research. $2^{\text {nd }}$ edn.IRRI, Los Banos, Philippines. p. 207215.

Jackson, M.L. 1973. Soil Chemical Analysis. Prentice Hall of India Pvt. Ltd., New Delhi. p. 151-154.

Man, L.H. and Ha, N.N.2006. Effect of decomposed rice straw at different times on rice yield. Omonrice. 14: 58-63.

Olsen, S.R., Cole, C.V., Watanable, F.S. and Dean, L.A. 1954. Estimation of available phosphorus in soils by extraction with sodium bicarbonate. U.S. Dept. Agric. Res., p. 929.

Page, A.L., Miller, R.H. and Keeney, D.R. 1982. Methods of Soil Analysis, Part-2. $2^{\text {nd }}$ Edn. American. Soc. Agron. Inc. Madison, Washington, USA. p. 98-765.

Patil, M.B., Mohammed, R.G. and Ghadge, P.M. 2004. Effect of organic and inorganic fertilizers on growth, yield and quality of tomato. J. Maharashtra Agricultural University, 29(2): 124-127.

Reddy, B.N., Sinha, M.N. and Rai, R.K. 1998. Effect of irrigation, nitrogen and phosphorus on nitrogen and phosphorus uptake by mustard (Brassica juncea) at various stage of growth. Ann. Agril. Res., 9(1): 129-133.

Sittu, G.A. and Adelekha, J.A. 1999. Effect of gibberellic acid on the growth and development of tomato (Lycopersicon esculentum Mill.). Cultivar 158-163. Global J. Pure Appl. Sci., 5(1): 27-30.

Wu, C.W., Lin, J.Y., Tarug, S.F. and Cheeru, J.L. 1983. Effect of plant growth regulators on the growth and development of tomato. J. Agric. Assoc., 124: 31-42.

Yongchung, Z., Shen, Q., Sun, Y.L., Liu, H., Ki, Q., Xin, H. and Wang, Z. 2004. Effects of application of nitrogen fertilizers of different $\mathrm{N}$ forms on yields and quality at chinese cabbage. Jiangsu J. Agril. Sci., 20(3): 184-188.

Zhang, C.X., Chen, Y.M., Fu, J.H., Cheng, S.Z. and Lin, F.Y. 2009. Greater vegetable and fruit intake is associated with a lower risk of breast cancer among chinese women. Inter. J. Cancer, 125(1): 8-18. 